\title{
The Implications of Renewable and Non-renewable Energy Generating in Sub-Saharan Africa: The Role of Economic Policy Uncertainties
}

\author{
Festus Fatai Adedoyin \\ Department of Accounting, Finance and Economics, \\ Bournemouth University, United Kingdom. \\ Email: fadedoyin@bournemouth.ac.uk
}

\author{
Ilhan Ozturk \\ Corresponding author \\ Faculty of Economics and Administrative Sciences, \\ Cag University, Mersin-Turkey. Email: ilhanozturk@,cag.edu.tr
}

Mary Oluwatoyin Agboola

College of Business, Dar Al Uloom University, 1MizanSt. Al Falah, Riyadh 13314 Saudi Arabia. E-mail: maryagboola@dau.edu.sa

Phillips O. Agboola

Mechanical Engineering Department, College of Applied Engineering, King Saud University (Al Muzahimiyah Branch), Riyadh, Saudi Arabia.

E-mail: pagboola@ksu.edu.sa

Festus Victor Bekun

Faculty of Economics Administrative and Social sciences, Istanbul Gelisim University, Istanbul, Turkey.

$\&$

Department of Accounting, Analysis and Audit, School of Economics and Management South Ural State University, 76, Lenin Aven., Chelyabinsk, Russia 454080.

E-mail: fbekun@gelisim.edu.tr

\begin{abstract}
:
Sub-Saharan Africa which is one of the main regions known for various sources of mineral and energy resources in the global market has experienced appreciable rates of economic expansion in the last 10 years. However, apart from the environmental consequences of generating energy, how uncertainties in the economy moderate the impact of energy generation on the environment is yet to be given desired attention. Hence, this study investigates the role of economic policy uncertainty in the energy-growth-emissions nexus for 32 countries in Sub-Saharan Africa over the period from 1996 to 2014. Results from one-step system-GMM show that real GDP and generation of non-renewable energy both increases CO2 emissions. However, while economic policy uncertainty also propels high levels of emissions in the region, its moderation effect on the impact of both renewable and non-renewable energy generation leads to a reduction in emissions level in the region. This suggests an urgent need for the implementation of sound macroeconomic and energy policies in Sub-Saharan Africa to safeguard the energy sector from disruptions and to mitigate the resultant impact on the degradation of the environment in the region.
\end{abstract}

Keywords: Renewable Energy Generation; Non-renewable Energy Generation; CO2 Emissions; Economic Growth; Economic Policy Uncertainty; Sub-Saharan Africa. 


\section{Introduction}

Energy consumption and its attendant environmental consequences have been one of the main discourses in the energy literature for several decades. The rationale for such popularity is rooted in the increasing levels of environmental degradation, frequent and damage-rendering oil shocks and the availability of renewable forms of energy which have all contributed to a closer interest in energy and environmental economics. However, in the addendum to most studies which emphasis e the role of energy consumption in the nexus, the energy sector as depicted by Ackah and Kizys (2015) is regarded as a key driver of an economy, through making available the energy needed for heating, lighting and transport. Oil accounts for a third of the fuel used in power generation worldwide (Eren, Taspinar, \& Gokmenoglu, 2019). Subsequently, the level of a country's growth and development depends, to a large extent, on its level of energy generation.

Most countries in the Sub-Saharan Africa (SSA) region rely on carbon-emitting nonrenewable energy as their main source of energy, because, given the high population of the continent, rising levels of energy and power are needed to meet the increasing energy demand. Energy is regarded as the wheels of an economy (Ozcan \& Ozturk, 2019). However, the shortage of power is still very much in evidence in some parts of Africa, as $63 \%$ of the SubSaharan African population lack access to electricity (da Silva, Cerqueira, \& Ogbe, 2018). This claim is supported by Ackah and Kizys (2015), affirming that a whopping 585 million people in Sub-Saharan Africa lack access to electricity. Given the majority of Sub-Saharan Africa is mired in a vicious circle of poverty, the damning evidence regarding energy generation sheds more light on the problem and points at a direct relationship between energy consumption and economic growth.

Additionally, non-renewable energy, in the form of oil, is the major source of energy, and this brings both positive and negative effects alike. According to Adams, Klobodu, and Apio (2018), a 10\% rise in non-renewable energy consumption corresponds to a $2.11 \%$ rise in GDP. Despite this seemingly favorable outcome, many countries in the world are seeking alternative sources of energy to curtail the adverse effects of non-renewable energy sources on environmental quality. The adverse effects of oil usage are multifaceted, economy-threatening and environment-unfriendly. Ozcan and Ozturk (2019) cite problems of low energy security, high and volatile oil prices, while Destek and Aslan (2017) mention issues regarding inexplicable erratic price shifts. 
Despite these concerns, the biggest reason for a diversion from non-renewable energy to renewable energy consumption is the severe and long-lasting environmental effects (Apergis, Payne, Menyah, \& Wolde-Rufael, 2010; Dogan, 2016; Destek, 2016; Destek \& Aslan, 2017; Ozcan \& Ozturk, 2019; da Silva et al., 2018). Increased carbon emissions, oil spillage, oil flaring and massive deforestation are all heads of the hydra termed environmental degradation. The rising levels of environmental decadence have attracted the attention of governments, policymakers, researchers and international bodies and, as such, in a bid to improve the environment quality, the Africa Renewable Energy Initiative was created, to escalate access to and usage of renewable energy.

Furthermore, there exists a significant potentiality of African countries to gear their efforts towards the adoption of cleaner energy sources. Wide landmass exists for erection of windmills and turbines to harness the wind (Ackah \& Kizys, 2015), there is availability of river bodies for hydropower (da Silva et al., 2018) and year-round sunshine for solar power. Despite certain countries like Kenya and Ethiopia harnessing geothermal energy on a considerable scale (da Silva et al., 2018), renewable energy adoption is on the low side due to huge start-up and operating costs (Eren et al., 2019) and poor infrastructure (Adams et al., 2018). The rising levels of income and industrialization have brought about the degrading of the environment in Africa (Acheampong, 2018). This phenomenon is explained by the Environmental Kuznets Curve (EKC), which points at an inverse relationship between economic growth and environmental quality up to a threshold point.

However, from the literature, energy generation can be influenced by economic policy uncertainties (EPU), in form of price fluctuations and heavy dependency on foreign nations. Consequently, the current study finds peculiarity in the fact that energy generation has not been examined so far through the lens of economic policy uncertainties, with most papers focusing on energy causality nexus (Acheampong, 2018; Adams, Klobodu \& Apio, 2018; Apergis et al., 2010; Aydin, 2019; Destek, 2016; Destek \& Aslan, 2017; Dogan, 2016; Ozcan \& Ozturk, 2019; Tugcu, Ozturk, \& Aslan, 2012; Zafar, Shahbaz, Hou, \& Sinha, 2019) and determinants of energy demand (Adewuyi, 2016; da Silva et al., 2018; Ulusoy \& Demiralay, 2017).

Economic policy uncertainties could be a factor to be considered when discussing the level of energy consumption in an economy, given that government policies are geared towards creating a more conducive macroeconomic environment for energy supply, in form of subsidies and direct investment. This raises investment in the energy sector, and, subsequently, an increase in both energy generation and consumption. On the other hand, economic policy uncertainties have the ability to cause stunted energy generation in Africa through price shocks and oil 
shortages. This would be paramount in many African nations, many of whom are importdependent, especially in terms of energy consumption. This forms the basis of the contribution of this current study to the existing knowledge on energy discourse, by identifying the direct effects of economic policy uncertainties on energy generation in Africa.

Similarly, the environmental consequences of non-renewable energy generation and consumption are a common thread of thought in the literature. Conversely, this study aims to examine how EPU moderates the environmental consequences of both renewable and nonrenewable energy generation alike.

To further strengthen the introduction of EPU in the energy-growth-emissions nexus, it is important to note that the vast majority of fossil fuels are imported from the Middle Eastern nations, many of which are embroiled in deep strife, largely believed to be as a result of the scramble for oil (Mohamed, Jebli, \& Youssef, 2019). This creates a problem of energy insecurity which manifests in the form of heavy dependency on foreign energy sources, erratic supply of oil and fluctuations in oil prices (Eren et al., 2019; da Silva et al., 2018). To reduce the devastating effects, governments could reduce energy importation, leading to a reduction in energy consumption and, hence, this would give a flatter environmental Kuznets curve (EKC). Apergis et al. (2010) point to the catch-22 dilemma of meeting the rising demand for energy and coping with greenhouse gas emissions, according to the feedback hypothesis which puts forward the idea that a bidirectional causality exists between energy consumption and economic growth (Destek \& Aslan, 2017; Dogan, 2016).

Moreover, the quest to attain sustainable development worldwide has changed the outlook on the energy sphere. Yao, Zhang, and Zhang (2019) assert that soaring carbon levels are a primary impact of economic growth. The release of greenhouse gases owing to burning of fossil fuels is regarded as a worldwide issue, with initiatives like the Kyoto Protocol and Sustainable Energy for All (SE4ALL) created to protect the environment from degradation and control the climate change. In Africa, unsurprisingly, non-renewable energy has a greater positive relationship with economic growth (Adams et al., 2018). Investment in renewable energy, however, is on the rise in developing countries, a testament to the belief they have reached the highest point on the EKC. Subsequently, rising income in Africa will come at the cost of less environmental pollution (Yao, Zhang, \& Zhang, 2019).

The next section presents an interesting review of the literature on generation and consumption of energy and its attendant environmental consequences as well as discussion of the role of uncertainty in the nexus. This is followed by the methodology section with detail on 
data used for the study. Section four discusses the results with important policy implications, while the study concludes in section five with important energy and macroeconomic policy recommendations.

\section{Literature Review}

\subsection{Renewable and Non-renewable Energy, Economic Growth and Environmental Degradation}

Like energy consumption, which has both growth and environmental consequences Alola, A.A., \& Bekun, 2020a; Adedoyin, Gumede, Bekun, Etokakpan, \& Balsalobre-Lorente, 2020b, Etokakpan. Adedoyin, Vedat, \& Bekun et al., 2020; Kirikkaleli. Adedoyin, \& Bekun, 2020; Udi,Bekun, \& Adedoyin, 2020), the diverse yet intertwined concepts of renewable energy and non-renewable energy generation, economic growth and environmental degradation have garnered attention globally, and a rising interest exists in the field. Nevertheless, despite various results obtained and various inferences drawn, a similar likeness exists among the literature in explaining the relationship between these variables. The energy-growth nexus revolves around four major hypotheses, namely, growth hypothesis, conservation hypothesis, feedback hypothesis and neutrality hypothesis (Acheampong, 2018; Adams et al., 2018; Apergis et al., 2010; Aydin, 2019; ; Destek, 2016; Destek \& Aslan, 2017; Dogan, 2016; Ozcan \& Ozturk, 2019; Tugcu et al., 2012; Zafar et al., 2019 and).

The growth hypothesis refers to a one-way causality between energy consumption and economic growth and claims economic growth is dependent on the extent of energy consumption in the economy Acheampong, 2018; Adams et al., 2018; Zafar et al., 2019). In the event of the reverse, where economic growth becomes the basis for energy consumption, the conservation hypothesis is upheld, according to which shocks to economic growth have an impact on energy consumption in a unidirectional manner (Destek \& Aslan, 2017). However, where a two-way causality exists between energy consumption and economic growth such that both variables can assume the position of dependency on the other, a feedback hypothesis ensues (Aydin, 2019; Tugcu et al., 2012). Lastly, the neutrality hypothesis occurs when no causal relationship is discovered between both variables. Simply put, it is characterized by zero empirical causality between energy consumption and economic growth. (Dogan, 2016; Ozcan \& Ozturk, 2019). 
In Africa, a series of researches has been carried out to ascertain the extent, causality and implications of renewable and non-renewable energy generation. One such is the work of Acheampong (2018), who adopted a panel autoregression alongside the system-generalized method of moments to examine the causal relationship between GDP growth, carbon emissions and energy consumption in 116 countries. The finding that a positive shock to GDP raises both energy consumption and carbon emissions in the short run, but stability in the long run, is synonymous with Paramati, Bhattacharya, Ozturk, \& Zakari (2018), who discovered that industrialization would lead to energy saving for most African countries.

The greater proportion of energy usage in SSA stems from non-renewable sources like petroleum products. Adewuyi (2016), aiming to ascertain the factors behind import demand for refined crude oil products in Nigeria from 1984 to 2013, submitted that the import of kerosene, distillate fuel and premium motor spirits in Nigeria has remained high over the years, with the motor spirit (commonly called petrol) the highest of all three. Adams et al. (2018) set out to verify the ripple effect of energy consumption in thirty Sub-Saharan African countries. Using a Westerlund panel-based error correction test, their results showed a 10\% rise in non-renewable energy consumption corresponded to a $2.11 \%$ increment in GDP, in stark contrast to a $0.27 \%$ rise in GDP for a similar 10\% rise in renewable energy consumption.

Regarding the burgeoning usage and rising importance of renewable energy, certain papers sought to provide reasons for the low levels of renewable energy usage and corresponding emission levels in SSA countries. da Silva, Cerqueira, and Ogbe (2018) examined the factors behind renewable energy growth in Sub-Saharan Africa. The results of their panelauto regressive distributed lag showed stunted economic development has inhibited the full adoption and implementation of renewable energy, despite an abundance of resources. Ozcan and Ozturk (2019) are not far off from this view, opining that rising urbanization and teeming population levels in LDCs are responsible for less attention being paid to renewable energy production. Consequently, greater focus is on other sectors like transportation and industry.

\subsection{Generation of Energy and Economic Policy Uncertainty in Africa}

Energy generation comprises a large web of various causative factors and resultant effects. It is influenced by diverse economic policies and shocks and similarly affects the economy. Since both renewable and non-renewable energy are geared toward the same goal, which is the provision of power to the populace of a country for diverse yet interrelated purposes, by and large, the same effects plague them. 
Despite a significant portion of the literature focusing on the relationship between energy consumption and growth, and the environmental effects of non-renewable energy usage, the relationship between energy generation and economic policy uncertainties has been broached by only a few authors.

A slight distinction exists between the papers that emphasize the aspects of shocks in the economy and those that refer to unpredictable effects of government policies.

According to Adams et al. (2018), verdicts of governments and policy makers are vital in determining the energy-growth performance. Adopting a Westerlund panel-based error correction test for thirty Sub-Saharan African countries, their findings showed nations with more stable governments had a higher growth rate in renewable energy growth. This can probably be attributed to the fact that stability ensured better policies were enacted which favored the growth of the energy sector. On the issue of government policies, Destek (2016) regarded economic incentives in the form of tax reliefs and subsidies a key method of attracting investors and raising investment for renewable energy adoption. In a not too dissimilar view, da Silva et al. (2018) opined that the provision of green certificates, quotas and provision of direct investment would be beneficial in driving renewable energy production, particularly in LDCs, which are characterized by low levels of income and wealth.

Having examined the effect of government policies on energy generation, a common line of thought exists as regard shocks and their impacts on the energy sphere. Price shocks, oil shortages and trade imbalances are common uncertainties associated with energy generation and are regarded in the literature as a secondary, albeit important, motive for renewable energy adoption. da Silva et al. (2018) identified price volatility as a key factor affecting energy consumption. Frequent oil shocks put economies in a precarious position, especially SSA nations, which are majorly import dependent. This creates a problem of low energy security, as the determinant of energy consumption and price in such countries would be dependent on global market phenomena. Ozcan and Ozturk (2018), examining the relationship between renewable energy consumption and economic growth in seventeen emerging economies, including Egypt and South Africa, discovered that high and volatile oil prices have been a major factor accelerating renewable energy consumption, and the desire to have more energy security is a vital component of renewable energy adoption.

The consensus in the literature is that economic policy uncertainties serve as catalysts for the declining appeal of non-renewable energy and springboards for the rapid rise of renewable 
energy consumption. Price shocks, energy security, oil and gas shortages and dependency on other countries serve as motives for renewable energy adoption by various countries worldwide.

Despite the growing appeal of renewable energy, it is also plagued by some economic uncertainties which have served to delay its adoption. Having expatiated on the effect of government policies as a driver or dampener of renewable energy usage, the huge start-up costs have been roundly pointed to as a stumbling block behind its relatively slow growth.

Eren, Taspinar, and Gokmenoglu (2019), studying the impact of financial development on renewable energy consumption, submitted that start-up costs and high cost of investment could be a stumbling block for LDCs in their path to renewable energy adoption. This is akin to the view of Adams et al. (2018), stating that the low level of investment in renewable energy keeps it at a babyhood stage. This, thereby, ensures the renewable energy consumption remains at a stunted level. Destek (2016) weighs in on the discourse, concluding that a low level of investment on renewable energy coupled with high costs could be detrimental to economic activities.

The slow growth of renewable energy adoption and continued non-renewable energy consumption would lead to further carbon emissions and steady environmental degradation. Nevertheless, African countries still keep moving along the EKC curve, although at a languid pace.

Global warming as a result of the burning of fossil fuels like coal, natural gas and oil has been recognized in the literature as the major driver of environmental degradation. However, Sarkodie and Adom (2018) regard desertification in Kenya to be a big problem in hastening the pace of global warming. Using a nonlinear iterative partial least squares method to examine determinants of energy consumption in Kenya, they posited that rising population created more strain on available energy sources, and about $80 \%$ of the populace used wood for cooking and heating purposes.

On balance, as regard energy generation, there exists a big gulf between the north and the Sub-Saharan African countries. Economically, and on the development path, North African countries have been ahead of their Sub-Saharan counterparts. In the energy sector and energy generation, no deviation from the trend exists. According to da Silva et al. (2018), over 99\% of North Africans have access to electricity; this is in stark contrast to just 31\% of Sub-Saharan Africans enjoying electricity (Ackah \& Kizys, 2015). While no concrete reason exists for this disparity, a number can be hypothesized - government policies and various growth and 
development trajectories. The nexus between energy and uncertainties is deeply interwoven and various inferences can be drawn from it ${ }^{1}$.

\section{Data and Methods}

\subsection{Data and Variables}

The study makes use of data spanning over the period from 1996 to 2014. A major setback to the timespan is due to the lack of data on Sub-Saharan African (SSA) as, although the economic policy uncertainty (EPU) data are available from 1996 to 2018, they are only available for 32 SSA countries. While emissions data limit the data for SSA countries, on the one hand, EPU limits the data span for our regional analysis of SSA countries on the other hand. Additionally, data on energy generation and CO2 emissions are available up to 2014 for the selected countries. Table 1 presents data sources as well as the proxy for each variable, while the author computed the data for the interaction between economic policy uncertainty and nonrenewable energy, and between economic policy uncertainty and renewable energy.

Table 1. Description of variables

\begin{tabular}{|l|l|l|}
\hline \multicolumn{1}{|c|}{ Variables } & \multicolumn{1}{|c|}{ Description } & \multicolumn{1}{|c|}{ Source } \\
\hline LCO2 & $\begin{array}{l}\text { Carbon dioxide emissions, thousands of } \\
\text { tonnes }\end{array}$ & The World Bank \\
\hline LRGDP & $\begin{array}{l}\text { Gross Domestic Product, billions of } 2010 \\
\text { U.S. dollars }\end{array}$ & The World Bank \\
\hline LNREN & $\begin{array}{l}\text { The sum of gasoline production, Jet fuel } \\
\text { production and oil production (thousand } \\
\text { barrels per day) }\end{array}$ & $\begin{array}{l}\text { The U.S. Energy } \\
\text { Information } \\
\text { Administration }\end{array}$ \\
\hline EPU & $\begin{array}{l}\text { Renewable power generation, billion kilowatt- } \\
\text { hours }\end{array}$ & $\begin{array}{l}\text { The U.S. Energy } \\
\text { Information } \\
\text { Administration }\end{array}$ \\
\hline LREN*EPU & $\begin{array}{l}\text { This variable is generated as an interaction } \\
\text { term between renewable energy generation } \\
\text { and economic policy uncertainty }\end{array}$ & (Author calculation) \\
\hline LNREN*EPU & $\begin{array}{l}\text { This variable is generated as an interaction } \\
\text { term between non-renewable energy and } \\
\text { economic policy uncertainty }\end{array}$ & (Author calculation) \\
\hline
\end{tabular}

\footnotetext{
${ }^{1}$ For brevity, please see Table A.3 in the appendix for details on the literature review
} 


\subsection{Model and Method}

To analyze the impact of economic policy uncertainty, renewable energy generation and non-renewable energy generation on CO2 emissions in Sub-Saharan Africa, we adopt a carbon function in line with Adedoyin, Gumede, Bekun, Etokakpan, and Balsalobre-Lorente (2020b) which is given in equations 1 to 4 . However, unlike past studies, we utilize energy generation proxies, and introduce economic policy uncertainties (EPU) as well as its moderating effect.

$$
\begin{gathered}
C O 2=f(R E N, N R E N, \text { EPU, RGDP }) \\
C O 2_{i t}=\beta_{0}+\beta_{1} R E N_{i t}+\beta_{2} N R E N_{i t}+\beta_{3} E P U_{i t}+\beta_{4} R G D P_{i t}+\mu_{i t} \\
C O 2=f\left(\operatorname{REN}, N R E N, E P U, R G D P, R E N^{*} E P U, N R E N^{*} E P U\right) \\
C O 2_{i t}=\beta_{0}+\beta_{1} R E N_{i t}+\beta_{2} N R E N_{i t}+\beta_{3} E P U_{i t}+\beta_{4} R G D P_{i t}+\beta_{5} R E N * E P U_{i t} \\
+\beta_{6} R E N * E P U_{i t}+\mu_{i t}
\end{gathered}
$$

where; $\mathrm{CO}_{2}$, REN, NREN, EPU, RGDP, REN*EPU, NREN*EPU = value of the series; $\mu_{t}=$

Error term; and $\beta_{i}=$ the parameter for estimation.

This being a panel study makes use of data from 32 countries in Sub-Saharan Africa and utilizes panel data from countries over the period 1996 to 2014. Also: (1) the panel is subdivided into four regions in Sub-Saharan Africa, namely; West Africa, East Africa, Sothern Africa and Central Africa. Dynamic models have been adopted to establish the role of economic policy, renewable energy and non-renewable energy on the environment in the region.

Among the static models employed in estimating the models in the study are the pooled ordinary least squares (POLS), which by its nature does not recognize heterogeneities across panels, and the Fixed effects (FE) and Random Effects (RE) estimators which can recognize panel heterogeneities, while the system generalized method of moments (sys-GMM) as a dynamic model estimator is chosen above the static panel techniques.

\section{Results and Discussion}

\subsection{Pre-estimation Diagnostics: Descriptive Statistics and Correlation}

Table 2 presents the descriptive statistics for the study variables. GDP has the highest mean value and records the highest single value, while renewable energy is the most dispersed variable. On the other hand, economic policy uncertainty records the minimum value. Also, the 
Pearson correlation coefficient is a proportion of the quality and bearing of affiliation that exists between two variables and draws a line of best fit through the information of the two factors.

Table 2. Summary Statistics

\begin{tabular}{|l|r|r|r|r|r|}
\hline Variable & Obs. & Mean & Std. Dev. & Min & \multicolumn{1}{l|}{ Max } \\
\hline LCO2 & 608 & 7.9188 & 1.6019 & 4.8283 & 13.1286 \\
\hline LRGDP & 608 & 2.3776 & 1.3300 & -0.5108 & 6.1143 \\
\hline LREN & 511 & -0.0452 & 1.6387 & -4.6052 & 2.8232 \\
\hline LNREN & 511 & 3.7830 & 2.2361 & -1.8326 & 7.8902 \\
\hline EPU & 608 & 0.0509 & 0.0432 & 0.0000 & 0.2656 \\
\hline LNREN*EPU & 511 & 0.1957 & 0.2510 & -0.1204 & 2.0628 \\
\hline LREN*EPU & 511 & 0.0062 & 0.1076 & -0.3571 & 0.6644 \\
\hline
\end{tabular}

Table 3 presents the correlation matrix. Accordingly, there exists a positive and significant linear relationship between the independent variables LRGDP, LREN, LNREN, EPU, LNREN*EPU, LREN and the dependent variable LC02.

Table 3. Correlation Matrix

\begin{tabular}{|l|l|l|l|l|l|l|l|}
\hline & LCO2 & LRGDP & LREN & LNREN & EPU & LNREN*EPU & LREN*EPU \\
\hline LCO2 & 1 & & & & & & \\
\hline LRGDP & -- & & & & & \\
\hline & $0.9132^{*}$ & 1 & & & & & \\
\hline LREN & 0.0000 & -- & & & & & \\
\hline & $0.5210^{*}$ & $0.6539^{*}$ & 1 & & & & \\
\hline LNREN & 0.0000 & 0.0000 & -- & & & & \\
\hline
\end{tabular}




\begin{tabular}{|l|l|l|l|l|l|l|l|}
\hline & 0.0000 & 0.0000 & 0.0005 & -- & & \\
\hline EPU & $0.0941^{*}$ & 0.0477 & $0.1215^{*}$ & -0.0227 & 1 & & \\
\hline & 0.0203 & 0.2404 & 0.0059 & 0.7068 & -- & & \\
\hline LNREN*EPU & $0.3688^{*}$ & $0.4447^{*}$ & $0.1887^{*}$ & $0.5196^{*}$ & $0.7259^{*}$ & 1 & \\
\hline & 0.0000 & 0.0000 & 0.0025 & 0.0000 & 0.0000 & -- & \\
\hline LREN*EPU & $0.3788^{*}$ & $0.5012^{*}$ & $0.7598^{*}$ & $0.2308^{*}$ & $0.2382^{*}$ & $0.5238^{*}$ & 1 \\
\hline & 0.0000 & 0.0000 & 0.0000 & 0.0002 & 0.0000 & 0.0000 & -- \\
\hline
\end{tabular}

Bin scatter plot is a non-parametric technique used in understanding the connection between two or more variables. It groups the dependent variable into the same sized bins and calculates the average of the dependent variable within each bin. Bin scatter plot helps mirror how the population behaves and not just the behavior of the sample used in the study. Consequently, as shown in Figure 1, there is a positive relationship between LCO2 and the independent variables.

Figure 1. Bin scatter plots for variables of interest
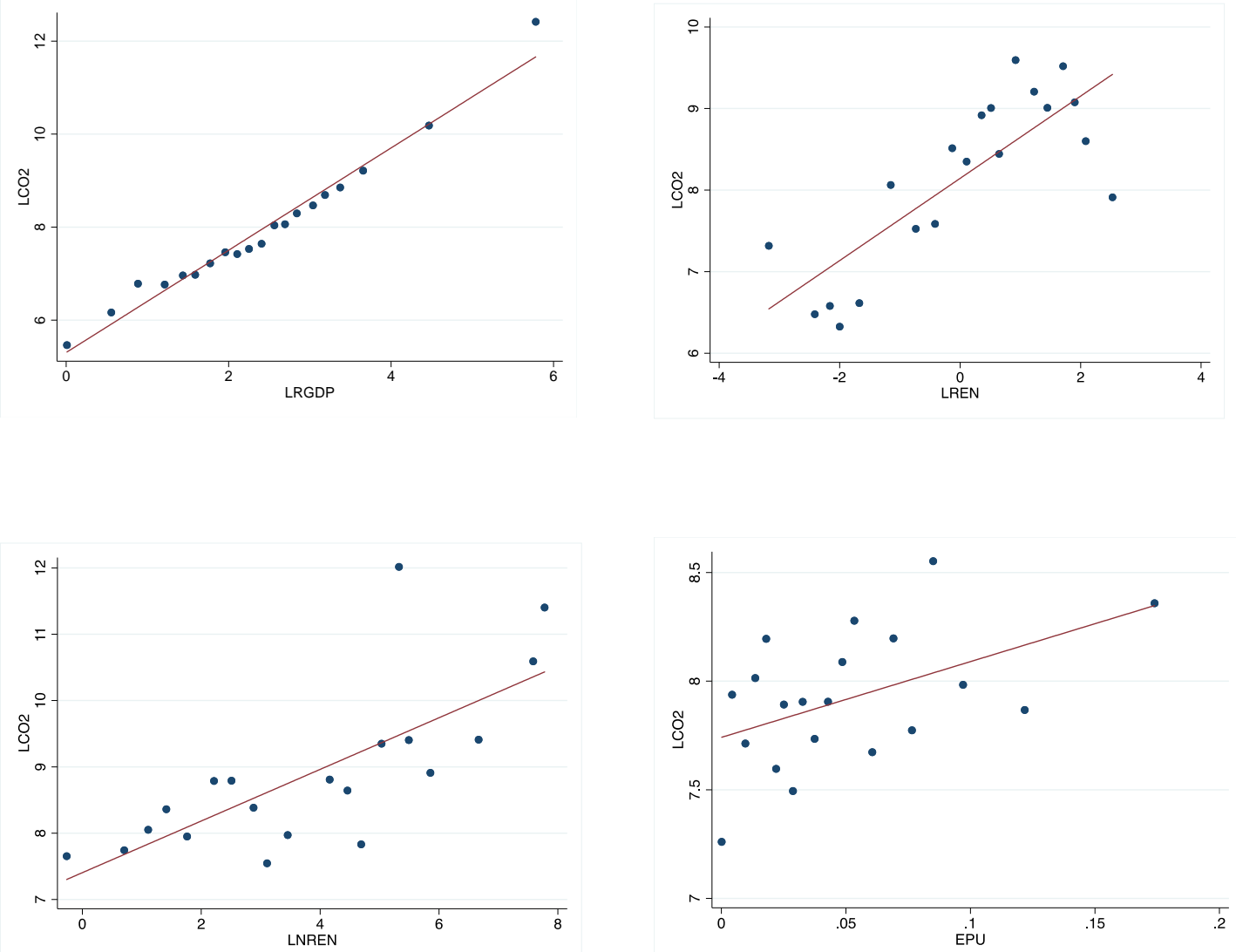


\subsection{Main Results}

Table 4 presents the results for the main model. The model is consistent with previous findings and is significant. Results across all four estimators (Pooled-OLS, Fixed Effects, Random Effects and GMM) reveal that GDP contributes significantly to raise emissions in Sub-Saharan Africa. This signifies that the expansion of economic activities in the region often involves the use of C02-emitting energy sources. Similar findings have been documented in the studies of Saidi and Hammami (2015) for 58 countries and Waqih. Bhutto, Ghumro, Kumar, and Salam (2019) for the SAARC region.

Consequently, renewable energy appears to contribute negatively to the level of emissions according to the Pooled OLS and GMM estimates. Specifically, the result implies that a $1 \%$ rise in the deployment of renewable energy resources in Sub-Saharan Africa will decrease the CO2 emissions by $0.0043 \%$ and $0.19 \%$, respectively, for the Pooled OLS and GMM estimates. The result found for renewable energy, as shown in the Pooled OLS and GMM estimates, is in accordance to a-priori expectation, as we expect renewable energy sources as an alternative to the carbon-emitting energy sources should decrease carbon emissions significantly. This finding concurs with the studies of Pata (2018) for Turkey, and Bilgili, Kocak, and Bulut (2016) for 17 OECD countries. However, further results from the FE and RE estimates reveal that increased capacity to generate renewable energy leads to high emissions in the region by $0.097 \%$ and $0.126 \%$, respectively.

Table 4. Results for Main Model Estimation across several techniques compared with One-Step System GMM. (Dep. Variable: CO2, log)

\begin{tabular}{|l|c|c|c|c|}
\hline \multicolumn{1}{|c|}{ Variables } & Pooled-OLS & $\begin{array}{c}\text { Fixed } \\
\text { Effects }\end{array}$ & $\begin{array}{c}\text { Random } \\
\text { Effects }\end{array}$ & $\begin{array}{c}\text { One-Step } \\
\text { System } \\
\text { GMM }\end{array}$ \\
\hline Lagged LCO2 & & & & $0.830^{* * *}$ \\
\hline & & & & $(0.0706)$ \\
\hline LRGDP & $1.378^{* * *}$ & $0.860^{* * *}$ & $0.909^{* * *}$ & $0.243^{* *}$ \\
\hline LREN & $(0.0584)$ & $(0.139)$ & $(0.137)$ & $(0.110)$ \\
\hline & $-0.196^{* * *}$ & $0.126^{* *}$ & $0.0973^{*}$ & $-0.0433^{*}$ \\
\hline LNREN & $(0.0247)$ & $(0.0525)$ & $(0.0530)$ & $(0.0210)$ \\
\hline & $-0.0808^{* * *}$ & $0.0510^{*}$ & $0.0507^{*}$ & 0.00254 \\
\hline EPU & $(0.0202)$ & $(0.0287)$ & $(0.0292)$ & $(0.0149)$ \\
\hline & -0.618 & -0.0870 & -0.117 & 2.564 \\
\hline & $(0.605)$ & $(0.399)$ & $(0.398)$ & $(1.463)$ \\
\hline
\end{tabular}




\begin{tabular}{|c|c|c|c|c|}
\hline \multirow{2}{*}{ Southern Africa } & 0.249 & & 0.517 & \\
\hline & $(0.158)$ & & $(0.703)$ & \\
\hline \multirow[t]{2}{*}{ Central Africa } & 0.00147 & & $-0.426^{* *}$ & \\
\hline & $(0.0730)$ & & $(0.192)$ & \\
\hline \multirow[t]{2}{*}{ Eastern Africa } & $-0.465^{* * *}$ & & $-0.778^{* * *}$ & \\
\hline & $(0.0631)$ & & $(0.259)$ & \\
\hline \multirow[t]{2}{*}{ Constant } & $5.108^{* * *}$ & $5.882^{* * *}$ & $6.003 * * *$ & $0.628^{* *}$ \\
\hline & $(0.161)$ & $(0.416)$ & $(0.377)$ & $(0.278)$ \\
\hline R-squared & 0.946 & 0.741 & & \\
\hline Year Dummies & Yes & Yes & Yes & - \\
\hline Instruments/Groups & - & - & - & $212 / 32$ \\
\hline Number of Country ID & 32 & 32 & 32 & 32 \\
\hline \multicolumn{5}{|c|}{ Post-estimation Diagnostics } \\
\hline Hansen $p$ value & - & - & - & 1.000 \\
\hline $\operatorname{AR}(2) p$ value & - & - & - & 0.610 \\
\hline Sargan ( $p$-value) & - & - & - & 0.000 \\
\hline Hausman (p-value) & - & \multicolumn{2}{|c|}{0.0035} & - \\
\hline \multicolumn{5}{|c|}{$\begin{array}{l}\text { Robust standard errors in parentheses } \\
\qquad * * * \mathrm{p}<0.01, * * \mathrm{p}<0.05,{ }^{*} \mathrm{p}<0.1\end{array}$} \\
\hline
\end{tabular}

Non-renewable energy, as expected, leads to escalating levels of emissions in SubSaharan Africa as shown by FE and RE estimates. Specifically, a 1\% rise in non-renewable energy consumption will lead to a rise in emissions between $0.0507 \%$ and $0.0510 \%$, as shown in the two models. Non-renewable energy sources, such as jet fuel, petroleum, coal and many others, have been established in the literature as the major emitter of carbon and other greenhouse gases to the environment. The continuous use of these energy sources could drive more environmental degradation through $\mathrm{CO} 2$ emissions, as supported in the studies of Bellaid and Youssef (2017) for Tunisia and Chen, Wang, and Zhong (2019) for China. However, nonrenewable energy is associated with a reduction in emissions as is shown by the pooled OLS estimates. This result is against a priori expectation.

Economic policy uncertainty has a positive but non-significant impact on emissions. This means that the effect of economic policy uncertainty is not enough to determine the levels of emissions in Sub-Saharan Africa.

Table 5 presents the result for the second model, which includes the moderation effect of EPU on non-renewable energy and renewable energy. The results for the model are quite different from those in Table 4. Similar to results in the model estimates presented in Table 4, the estimates in Table 5 agree that GDP contributes to increasing emissions in Sub-Saharan Africa. Economic expansion in the sub-continent still involves C02-emitting activities. Similar to earlier results (Table 4), renewable energy has both negative and positive impacts on emissions. On the one hand, the Pooled-OLS reveals that $1 \%$ increase in the consumption of renewable 
energy will lead to a fall in the overall level of emissions in the continent by $0.17 \%$, whereas the FE and RE estimates reveal that emissions will rise even with the increased use of renewable energy by $0.095 \%$. and $129 \%$. respectively. Also, non-renewable energy consumption leads to an escalation in the rate of emissions as expected. A $1 \%$ rise in the use of non-renewable energy will lead to a $0.0489 \%$ increase in the level of emissions in Sub-Saharan Africa as shown by the GMM estimates.

Furthermore, as shown in Table 5, economic policy uncertainty is associated with a rise in emissions. This entails that lack of stability in the macroeconomic environment could lead to high rates of emissions in Sub-Saharan Africa as reported by the Pooled and GMM estimates. The interaction term between economic policy uncertainty and non-renewable energy is associated with a reduction in emissions. This impact is evident from the pooled and GMM estimates. Specifically, the interaction between economic policy uncertainty and non-renewable energy is accompanied by a fall in emissions of up to $0.758 \%$ and $0.779 \%$. This result implies that most economies tend to reduce their consumption of energy resources as a result of the macroeconomic instabilities geared by the economic policy uncertainty. Similarly, the moderation effect of economic policy uncertainty on renewable energy leads to a fall in emissions by $1.032 \%$. As can be seen, the moderation impact of EPU on renewable energy leads to a higher reduction in emissions compared to the moderation impact of EPU on non-renewable energy. Also, this outcome points to shocks in the renewable energy sector owing to policy instability in the economic environment in the region.

Table 5. Results for Model with Moderation variables across several techniques compared with One-Step System GMM (Dep. Variable: CO2, log)

\begin{tabular}{|l|c|c|c|c|}
\hline \multicolumn{1}{|c|}{ Variables } & $\begin{array}{c}\text { Pooled- } \\
\text { OLS }\end{array}$ & $\begin{array}{c}\text { Fixed } \\
\text { Effects }\end{array}$ & $\begin{array}{c}\text { Random } \\
\text { Effects }\end{array}$ & $\begin{array}{c}\text { One-Step } \\
\text { System } \\
\text { GMM }\end{array}$ \\
\hline Lagged LCO2 & & & & $0.855^{* * *}$ \\
\hline & & & & $(0.0547)$ \\
\hline LRGDP & $1.384 * * *$ & $0.859^{* * *}$ & $0.921 * * *$ & $0.223^{* *}$ \\
\hline & $(0.0560)$ & $(0.146)$ & $(0.144)$ & $(0.0884)$ \\
\hline LREN & $-0.177 * * *$ & $0.129 * *$ & $0.0953^{*}$ & 0.0246 \\
\hline LNREN & $(0.0354)$ & $(0.0535)$ & $(0.0530)$ & $(0.0423)$ \\
\hline & -0.0319 & 0.0436 & 0.0439 & $0.0489^{* * *}$ \\
\hline EPU & $(0.0241)$ & $(0.0295)$ & $(0.0297)$ & $(0.0130)$ \\
\hline & $2.629 * *$ & -0.671 & -0.530 & $5.320^{* * *}$ \\
\hline LNREN*EPU & $(1.155)$ & $(0.601)$ & $(0.604)$ & $(0.837)$ \\
\hline
\end{tabular}




\begin{tabular}{|c|c|c|c|c|}
\hline & $(0.219)$ & $(0.115)$ & $(0.121)$ & $(0.206)$ \\
\hline \multirow[t]{2}{*}{ LREN*EPU } & -0.171 & 0.0451 & -0.0543 & $-1.032 * *$ \\
\hline & $(0.416)$ & $(0.275)$ & $(0.272)$ & $(0.463)$ \\
\hline \multirow[t]{2}{*}{ Southern Africa } & 0.227 & & 0.512 & \\
\hline & $(0.150)$ & & $(0.697)$ & \\
\hline \multirow[t]{2}{*}{ Central Africa } & -0.0562 & & $-0.415^{* *}$ & \\
\hline & $(0.0771)$ & & $(0.190)$ & \\
\hline \multirow[t]{2}{*}{ Eastern Africa } & $-0.486 * * *$ & & $-0.769 * * *$ & \\
\hline & $(0.0650)$ & & $(0.246)$ & \\
\hline \multirow[t]{2}{*}{ Constant } & $4.920 * * *$ & $5.914^{* * *}$ & $5.989 * * *$ & 0.288 \\
\hline & $(0.171)$ & $(0.450)$ & $(0.397)$ & $(0.232)$ \\
\hline R-squared & 0.949 & 0.743 & - & - \\
\hline Year Dummies & Yes & Yes & Yes & - \\
\hline Instruments/Groups & - & - & - & $212 / 32$ \\
\hline Number of Country ID & 32 & 32 & 32 & 32 \\
\hline \multicolumn{5}{|c|}{ Post-estimation Diagnostics } \\
\hline Hansen $p$ value & - & - & - & 1.000 \\
\hline $\operatorname{AR}(2) p$ value & - & - & - & 0.730 \\
\hline Sargan (p-value) & - & - & - & 0.003 \\
\hline Hausman ( $p$-value) & - & \multicolumn{2}{|c|}{0.0024} & - \\
\hline \multicolumn{5}{|c|}{$\begin{array}{l}\text { Robust standard errors in parentheses } \\
\qquad * * * \mathrm{p}<0.01, * * \mathrm{p}<0.05, * \mathrm{p}<0.1\end{array}$} \\
\hline
\end{tabular}

In Table A2, a comparison is made across the regions for the main models for four regions in Africa. The positive and significant coefficient for LRGDP indicates that economic expansion contributes significantly to high levels of emissions in all four regions. A $1 \%$ expansion in economic activities will escalate emissions by $0.91 \%, 1.5 \%, 0.449 \%$ and $2.36 \%$ in West, Southern, Central and East Africa regions, respectively. As can be seen, economic activities have the highest impact on emissions in East Africa, followed by Southern Africa and then West Africa and Central Africa. Renewable energy generation leads to a fall in emission in West Africa by an average of $0.034 \%$. This outcome is as expected given that continuous use of renewable energy cuts down carbon-emitting resources. On the other hand, it leads to an increase in emissions in Central and East Africa by $0.146 \%$ and $0.231 \%$. Renewable energy has no significant impact on emissions in Southern Africa.

On the other hand, non-renewable energy aggravates the number of emissions in Central Africa by $0.387 \%$. By its nature, non-renewable energy comprises of carbon releasing energy sources that contribute to high levels of emissions in the environment. A different result is recorded in rolled East Africa where non-renewable energy is associated with a reduction in emissions by $0.216 \%$. This implies that East African countries adopt controlled usage of energy 
in a way to mitigate the effects on the environment. However, non-renewable energy appears to have no significant impact on emissions in West and Southern Africa.

Consequently, results illustrate that Economic Policy Uncertainty (EPU) is a driver of emissions in West Africa as shown by the positive and significant coefficient for EPU. This result affirms that instability in the economic environment could aggravate emissions. On the other hand, EPU has no significant impact on emissions in the other three regions.

The Hansen tests for instrument validity show that the null hypothesis that instruments are valid should be accepted for the test. The autocorrelation (AR) test was also conducted to test for the presence of autocorrelation in the model. According to Batalgi (2003), there is expected to be low order autocorrelation (AR (1)) in the model, but not high order autocorrelation (AR (2)). Thus, the null hypothesis of no autocorrelation should be rejected for AR (1) and accepted for AR (2). The result presented above conforms to these expectations.

\section{Conclusion and Policy Implications}

Sub-Saharan Africa suffers from environmental crises such as floods, landslides, desertification and others that are aggravated by the accumulation of greenhouse gases such as C02 emissions in the course of economic activities and energy use. Similarly, the disruption of economic activities due to economic policy uncertainty could have a role in increasing the emissions and, consequently, have adverse effects on environmental quality. The motivation for this current study is embedded in the scant exploration of the nexus between economic policy uncertainty and carbon emissions in the literature. In this study, we, therefore, investigated the link between economic policy uncertainty, renewable energy, non-renewable energy, economic growth and C02 emissions for 32 countries in Sub-Saharan Africa over the period covering 1996 to 2014. We employed the use of Pooled OLS, Fixed Effects (FE), Random Effects Models and dynamic panel models such as the system-GMM estimators to analyze the equations in the study. Findings show that economic policy uncertainty propels high levels of emissions in Sub-Saharan Africa. Results also reveal that the moderation effects of economic policy uncertainty on renewable and non-renewable energy lead to a reduction in carbon emissions level in the region. 
Based on the results, several suggestions are put forward. Firstly, the study suggests that the governments in the regions should work toward the legislation and implementation of stable and visionary economic policies that will enable long-term macroeconomic stability to be secured. Also, the study suggests that the countries in the region work toward enlarging their capacity for the generation of renewable energy as part of their energy mix. Increased use of renewable energy will lead to a reduction of emissions in the region and will improve the quality of the environment as contained in the Sustainable Development Goal (SDG) 12.

However, this study is limited in that the conclusions based on its findings may not be suitable for individual countries. Hence, we suggest that individual studies be carried out, as they will be more suitable for policy making in the various countries. Further studies may also consider investigating non-linear interactions between economic policy uncertainty and environmental quality. Also, the data used for the regional analysis (West Africa, Southern Africa, Central Africa, East Africa) require some expansion. Future research can improve on the findings of this study where data are available for each region. This study, however, serves as a blueprint for future studies on modelling uncertainty in the energy literature.

Conflicts of Interest: The authors declare no conflict of interest.

\section{References}

Acheampong, A. O. (2018). Economic growth, CO2 emissions and energy consumption: What causes what and where? Energy Economics, 74, 677-692. https://doi.org/10.1016/j.eneco.2018.07.022

Acheampong, A. O., Adams, S., \& Boateng, E. (2019). Do globalization and renewable energy contribute to carbon emissions mitigation in Sub-Saharan Africa? Science of the Total Environment, 677, 436-446. https://doi.org/10.1016/j.scitotenv.2019.04.353

Ackah, I., \& Kizys, R. (2015). Green growth in oil-producing African countries: A panel data analysis of renewable energy demand. Renewable and Sustainable Energy Reviews, 50, 1157-1166. https://doi.org/10.1016/j.rser.2015.05.030

Adams, S., Klobodu, E. K. M., \& Apio, A. (2018). Renewable and non-renewable energy, regime type and economic growth. Renewable Energy, 125, 755-767. https://doi.org/10.1016/j.renene.2018.02.135

Adedoyin, F.F., Alola, A.A., \& Bekun, F.V. (2020a). An assessment of the environmental 
sustainability corridor: The role of economic expansion and research and development in EU countries. Science of the Total Environment, 713, 136726. https://doi.org/10.1016/j.scitotenv.2020.136726

Adedoyin, F.F., Gumede, I.M., Bekun, V.F., Etokakpan, U.M., \& Balsalobre-Lorente, D. (2020b). Modelling coal rent, economic growth and CO2 emissions: Does regulatory quality matter in BRICS economies? Science of the Total Environment, 710, 136284. https://doi.org/10.1016/j.scitotenv.2019.136284

Adewuyi, A. O. (2016). Determinants of import demand for non-renewable energy (petroleum) products: Empirical evidence from Nigeria. Energy Policy, 95, 73-93. https://doi.org/10.1016/j.enpol.2016.04.035

Ahir, H., Bloom, N., \& Furceri, D. (2018). The World Uncertainty Index. SSRN Electron. J. https://doi.org/10.2139/ssrn.3275033

Apergis, N., Payne, J. E., Menyah, K., \& Wolde-Rufael, Y. (2010). On the causal dynamics between emissions, nuclear energy, renewable energy, and economic growth. Ecological Economics, 69(11), 2255-2260. https://doi.org/10.1016/j.ecolecon.2010.06.014

Aydin, M. (2019). Renewable and non-renewable electricity consumption-economic growth nexus: Evidence from OECD countries. Renewable Energy, 136, 599-606. https://doi.org/10.1016/j.renene.2019.01.008

Belaid, F., \& Youssef, M. (2017). Environmental degradation, renewable and non-renewable electricity consumption and economic growth: Assessing the evidence from Algeria. Energy Policy, 102, 277-287.

Bilgili, F., Kocak, E., \& Bulut, U. (2016). The dynamic impact of renewable energy consumption on $\mathrm{CO} 2$ emissions: A revisited Environmental Kuznets curve approach. Renewable and Sustainable Energy Review, 54, 838-845.

Chen, Y., Wang, Z., \& Zhong, Z. (2019). CO2 emissions, economic growth, renewable and non-renewable energy production and foreign trade in China. Renewable Energy 131(2019), 208-216.

da Silva, P. P., Cerqueira, P. A., \& Ogbe, W. (2018). Determinants of renewable energy growth in Sub-Saharan Africa: Evidence from panel ARDL. Energy, 156, 45-54. https://doi.org/10.1016/j.energy.2018.05.068

Destek, M. A. (2016). Renewable energy consumption and economic growth in newly industrialized countries: Evidence from asymmetric causality test. Renewable Energy, 95, 478-484. https://doi.org/10.1016/j.renene.2016.04.049 
Destek, M. A., \& Aslan, A. (2017). Renewable and non-renewable energy consumption and economic growth in emerging economies: Evidence from bootstrap panel causality. Renewable Energy, 111, 757-763. https://doi.org/10.1016/j.renene.2017.05.008

Dogan, E. (2016). Analyzing the linkage between renewable and non-renewable energy consumption and economic growth by considering a structural break in time-series data. Renewable Energy, 99, 1126-1136. https://doi.org/10.1016/j.renene.2016.07.078

Eren, B. M., Taspinar, N., \& Gokmenoglu, K. K. (2019). The impact of financial development and economic growth on renewable energy consumption: Empirical analysis of India. Science of the Total Environment, 663, 189-197. https://doi.org/10.1016/j.scitotenv.2019.01.323

Etokakpan, M.U., Adedoyin, F.F., Vedat, Y., \& Bekun, F.V. (2020). Does globalization in Turkey induce increased energy consumption : insights into its environmental pros and cons? Environmental Science and Pollution Research, https://doi.org/10.1007/s11356$\underline{020-08714-3}$

Jingchao, Z., \& Kotani, K. (2012). The determinants of household energy demand in rural Beijing: Can environmentally friendly technologies be effective? Energy Economics, 34(2), 381-388. https://doi.org/10.1016/j.eneco.2011.12.011

Kirikkaleli, D., Adedoyin, F.F., \& Bekun, F.V. (2020). Nuclear energy consumption and economic growth in the UK : Evidence from the wavelet coherence approach. Journal of Public Affairs, 1-11.

Mohamed, H., Ben Jebli, M., \& Ben Youssef, S. (2019). Renewable and fossil energy, terrorism, economic growth, and trade: Evidence from France. Renewable Energy, 139, 459-467. https://doi.org/10.1016/j.renene.2019.02.096

Ozcan, B., \& Ozturk, I. (2019). Renewable energy consumption-economic growth nexus in emerging countries: A bootstrap panel causality test. Renewable and Sustainable Energy Reviews, 104, 30-37. https://doi.org/10.1016/j.rser.2019.01.020

Paramati, S. R., Bhattacharya, M., Ozturk, I., \& Zakari, A. (2018). Determinants of energy demand in African frontier market economies: An empirical investigation. Energy, 148, 123-133. https://doi.org/10.1016/j.energy.2018.01.146

Pata. U.K. (2018). The influence of coal and noncarbohydrate energy consumption on CO2 emissions: Revisiting the environmental Kuznets curve hypothesis for Turkey. Energy, 160 (2018), 1115-1123.

Saidi, K., \& Hamamami, S. (2015).The impact of co2 emissions and economic growth on energy consumption in 58 countries. Energy Reports, 1(2015), 62-70. 
Saint Akadiri, S., Alola, A. A., Akadiri, A. C., \& Alola, U. V. (2019). Renewable energy consumption in EU-28 countries: Policy toward pollution mitigation and economic sustainability. Energy Policy, 132 (February), 803-810. https://doi.org/10.1016/j.enpol.2019.06.040

Sarkodie, S. A., \& Adom, P. K. (2018). Determinants of energy consumption in Kenya: A NIPALS approach. Energy, 159, 696-705. https://doi.org/10.1016/j.energy.2018.06.195

Tugcu, C. T., Ozturk, I., \& Aslan, A. (2012). Renewable and non-renewable energy consumption and economic growth relationship revisited: Evidence from G7 countries. Energy Economics, 34(6), 1942-1950. https://doi.org/10.1016/j.eneco.2012.08.021

Udi, J., Bekun, F.V., \& Adedoyin, F.F. (2020). Modelling the nexus between coal consumption, FDI inflow and economic expansion: does industrialization matter in South Africa? Environmental Science and Pollution Research, 27, 10553-10564. https://doi.org/10.1007/s11356-020-07691-x

Ulusoy, V., \& Demiralay, S. (2017). Energy demand and stock market development in OECD countries: A panel data analysis. Renewable and Sustainable Energy Reviews, 71, 141-149. https://doi.org/10.1016/j.rser.2016.11.121

Waqih, M. A. U., Bhutto, N. A., Ghumro, N. H., Kumar, S. \& Salam, M. A. (2019). Rising environmental degradation and impact of foreign direct investment: An empirical evidence from SAARC region. Journal of Environmental Management, 243, 472-480.

Yao, S., Zhang, S., \& Zhang, X. (2019). Renewable energy, carbon emission and economic growth: A revised environmental Kuznets Curve perspective. Journal of Cleaner Production, 235, 1338-1352. https://doi.org/10.1016/j.jclepro.2019.07.069

Zafar, M. W., Shahbaz, M., Hou, F., \& Sinha, A. (2019). From nonrenewable to renewable energy and its impact on economic growth: The role of research \& development expenditures in Asia-Pacific Economic Cooperation countries. Journal of Cleaner Production, 212, 1166-1178. https://doi.org/10.1016/j.jclepro.2018.12.081

\section{Appendix}

Table A.1. List of countries in the sample

\begin{tabular}{|l|l|l|l|}
\hline \multicolumn{1}{|c|}{ West Africa } & Southern Africa & \multicolumn{1}{|c|}{ Central Africa } & \multicolumn{1}{c|}{ East Africa } \\
\hline Benin & Botswana & Angola & Burundi \\
\hline Burkina Faso & Lesotho & Cameroon & The Democratic Republic of the \\
\hline
\end{tabular}




\begin{tabular}{|c|c|c|c|}
\hline & & & Congo \\
\hline Ghana & Madagascar & $\begin{array}{l}\text { The central African } \\
\text { Republic }\end{array}$ & Kenya \\
\hline Guinea & Malawi & Chad & Rwanda \\
\hline Guinea-Bissau & Mozambique & Ethiopia & Sudan \\
\hline Ivory Coast & South Africa & Gabon & Tanzania \\
\hline Mali & & & Uganda \\
\hline Mauritania & & & Zambia \\
\hline \multicolumn{4}{|l|}{ Niger } \\
\hline \multicolumn{4}{|l|}{ Nigeria } \\
\hline \multicolumn{4}{|l|}{ Senegal } \\
\hline \multicolumn{4}{|l|}{ Togo } \\
\hline $\begin{array}{l}t=19 \\
i=12 \\
N=228\end{array}$ & $\begin{array}{l}t=19 \\
i=6 \\
N=114\end{array}$ & $\begin{array}{l}t=19 \\
i=6 \\
N=114\end{array}$ & $\begin{array}{l}\mathrm{t}=19 \\
\mathrm{i}=12 \\
\mathrm{~N}=152\end{array}$ \\
\hline
\end{tabular}

Table A.2. Pooled OLS (or LSDV) for comparative analysis across the 4 sub-regions in Sub-Sabaran Africa.

Dependent variable: LCO2

\begin{tabular}{|l|c|c|c|c|}
\hline Variables & West Africa & $\begin{array}{c}\text { Southern } \\
\text { Africa }\end{array}$ & $\begin{array}{c}\text { Central } \\
\text { Africa }\end{array}$ & East Africa \\
\hline LRGDP & $0.917 * * *$ & $1.504 * * *$ & $0.449 * * *$ & $2.363^{* * *}$ \\
\hline & $(0.0360)$ & $(0.0866)$ & $(0.102)$ & $(0.126)$ \\
\hline LREN & $-0.0341 * *$ & 0.0700 & $0.146^{* *}$ & $0.231^{* *}$ \\
\hline LNREN & $(0.0151)$ & $(0.0839)$ & $(0.0578)$ & $(0.103)$ \\
\hline EPU & 0.00611 & -0.00411 & $0.387 * * *$ & $-0.216^{* * *}$ \\
\hline Constant & $(0.0181)$ & $(0.0667)$ & $(0.0513)$ & $(0.0330)$ \\
\hline & $1.110^{* * *}$ & 0.192 & -0.838 & 0.152 \\
\hline Year Dummies & $(0.387)$ & $(1.150)$ & $(0.891)$ & $(0.811)$ \\
\hline R-squared & $6.032^{* * *}$ & $4.488^{* * *}$ & $5.174^{* * *}$ & $1.689^{* * *}$ \\
\hline & $(0.0952)$ & $(0.170)$ & $(0.104)$ & $(0.497)$ \\
& Yes & Yes & Yes & Yes \\
\hline & $\begin{array}{c}0.983 \\
\text { Robust standard errors in parentheses } \\
* * *\end{array}<0.01, * * \mathrm{p}<0.05, * 0.1$ & 0.892 \\
\hline
\end{tabular}


Table A.3. Summary of Past Literature

\begin{tabular}{|c|c|c|c|c|c|c|}
\hline $\mathbf{S} / \mathbf{N}$ & Authors \& Year & Aim & Country & Methodology & Findings & Causality Nexus \\
\hline 1. & $\begin{array}{l}\text { Ozcan and Ozturk } \\
(2019)\end{array}$ & $\begin{array}{l}\text { To analyse the relationship } \\
\text { between renewable energy } \\
\text { consumption and economic } \\
\text { growth }(1990-2016)\end{array}$ & $\begin{array}{l}17 \text { emerging } \\
\text { economies }\end{array}$ & $\begin{array}{l}\text { Bootstrap panel } \\
\text { causality test }\end{array}$ & $\begin{array}{l}\text { No causality exists } \\
\text { between renewable } \\
\text { energy consumption } \\
\text { and growth }\end{array}$ & $\begin{array}{l}\text { Neutrality } \\
\text { hypothesis }\end{array}$ \\
\hline 2. & Dogan (2016) & $\begin{array}{l}\text { To analyse the short and } \\
\text { long-run estimates and the } \\
\text { causality relationship } \\
\text { between economic growth, } \\
\text { renewable and non- } \\
\text { renewable energy } \\
\text { consumption in Turkey } \\
(1988-2012)\end{array}$ & Turkey & $\begin{array}{l}\text { Johansen } \\
\text { cointegration test, } \\
\text { Auto Regressive } \\
\text { Distributed Lag, } \\
\text { Cumulative sum of } \\
\text { squares, Vector Error } \\
\text { Correction Model, } \\
\text { Granger Causality } \\
\text { Test, Zivot-Andrews } \\
\text { unit root test }\end{array}$ & $\begin{array}{l}\text { Renewable energy } \\
\text { consumption has no } \\
\text { significant effect on } \\
\text { economic growth and } \\
\text { real GDP }\end{array}$ & $\begin{array}{l}\text { Neutrality } \\
\text { hypothesis }\end{array}$ \\
\hline 3. & $\begin{array}{l}\text { Destek and Aslan } \\
\text { (2017) }\end{array}$ & $\begin{array}{l}\text { To delve into the relative } \\
\text { performance of renewable } \\
\text { and non-renewable energy } \\
\text { consumption on economic } \\
\text { growth }(1980-2012)\end{array}$ & $\begin{array}{l}17 \text { emerging } \\
\text { economies }\end{array}$ & $\begin{array}{l}\text { Johansen } \\
\text { cointegration test, } \\
\text { Auto Regressive } \\
\text { Distributed Lag and } \\
\text { Vector Error } \\
\text { Correction Test }\end{array}$ & $\begin{array}{l}\text { For the most part, a } \\
\text { zero unidirectional } \\
\text { causality exists between } \\
\text { renewable energy } \\
\text { consumption and } \\
\text { economic growth }\end{array}$ & $\begin{array}{l}\text { Neutrality } \\
\text { hypothesis and } \\
\text { conservation } \\
\text { hypothesis }\end{array}$ \\
\hline
\end{tabular}




\begin{tabular}{|c|c|c|c|c|c|c|}
\hline $\mathbf{S} / \mathbf{N}$ & Authors \& Year & Aim & Country & Methodology & Findings & Causality Nexus \\
\hline 4. & Destek (2016) & $\begin{array}{l}\text { To examine the relationship } \\
\text { between positive and } \\
\text { negative shocks of } \\
\text { renewable energy } \\
\text { consumption and economic } \\
\text { growth in newly } \\
\text { industrialized countries } \\
(1971 \text { - 2011) }\end{array}$ & $\begin{array}{l}\text { Brazil, India, Turkey, } \\
\text { South Africa, Mexico } \\
\text { and Malaysia }\end{array}$ & $\begin{array}{l}\text { Asymmetric causality } \\
\text { approach, Auto } \\
\text { Regressive } \\
\text { Distributed Lag }\end{array}$ & $\begin{array}{l}\text { Negative shocks to } \\
\text { renewable energy } \\
\text { consumption lead to } \\
\text { negative shocks in real } \\
\text { GDP for South Africa } \\
\text { and Mexico, while } \\
\text { negative shocks lead to } \\
\text { negative shocks in real } \\
\text { GDP for India. } \\
\text { Neutrality hypothesis is } \\
\text { upheld in Brazil and } \\
\text { Malaysia }\end{array}$ & $\begin{array}{l}\text { Neutrality } \\
\text { hypothesis, growth } \\
\text { hypothesis }\end{array}$ \\
\hline 5. & $\begin{array}{l}\text { Tugcu, Ozturk, and } \\
\text { Aslan (2012) }\end{array}$ & $\begin{array}{l}\text { To examine the long run and } \\
\text { causal relationships between } \\
\text { renewable and non- } \\
\text { renewable energy } \\
\text { consumption and economic } \\
\text { growth, and comparing } \\
\text { which energy source is } \\
\text { prevalent (1980-2009) }\end{array}$ & G7 & $\begin{array}{l}\text { Auto-Regressive } \\
\text { Distributed Lag }\end{array}$ & $\begin{array}{l}\text { Feedback hypothesis } \\
\text { exists in all countries }\end{array}$ & $\begin{array}{l}\text { Feedback } \\
\text { hypothesis }\end{array}$ \\
\hline 6. & Aydin (2019) & $\begin{array}{l}\text { To explore the relationship } \\
\text { between renewable and non- } \\
\text { renewable electricity } \\
\text { consumption and economic } \\
\text { growth }(1980-2015)\end{array}$ & 26 OECD countries & $\begin{array}{l}\text { Pesaran LM test, } \\
\text { panel unit root test, } \\
\text { Dumitrescu-Hurlin } \\
\text { panel causality test }\end{array}$ & $\begin{array}{l}\text { Bidirectional causality } \\
\text { exists between non- } \\
\text { renewable electricity } \\
\text { consumption and } \\
\text { economic growth }\end{array}$ & $\begin{array}{l}\text { Feedback } \\
\text { hypothesis }\end{array}$ \\
\hline
\end{tabular}




\begin{tabular}{|c|c|c|c|c|c|c|}
\hline $\mathbf{S} / \mathbf{N}$ & Authors \& Year & Aim & Country & Methodology & Findings & Causality Nexus \\
\hline 7. & $\begin{array}{l}\text { Zafar, Shahbaz, } \\
\text { Hou, andSinha } \\
\text { (2019) }\end{array}$ & $\begin{array}{l}\text { To study the effects of } \\
\text { renewable and non- } \\
\text { renewable energy } \\
\text { consumption on economic } \\
\text { growth }(1990 \text { - 2015) }\end{array}$ & $\begin{array}{l}16 \text { (Asia-Pacific } \\
\text { Economic } \\
\text { Cooperation) } \\
\text { countries }\end{array}$ & $\begin{array}{l}\text { Continuously } \\
\text { Updated Fully } \\
\text { Modified OLS, } \\
\text { Cross-sectional ADF, } \\
\text { Cross-sectional } \\
\text { augmented IPS, } \\
\text { Westerlund } \\
\text { cointegration test }\end{array}$ & $\begin{array}{l}\text { Energy consumption } \\
\text { plays a driving role in } \\
\text { economic growth }\end{array}$ & $\begin{array}{l}\text { Growth hypothesis, } \\
\text { feedback } \\
\text { hypothesis }\end{array}$ \\
\hline 8. & $\begin{array}{l}\text { Apergis, Payne, } \\
\text { Menyah, and } \\
\text { Wolde-Rufael } \\
\text { (2010) }\end{array}$ & $\begin{array}{l}\text { To delve into the causal } \\
\text { relationship between carbon } \\
\text { dioxide emissions, nuclear } \\
\text { energy consumption, } \\
\text { renewable energy } \\
\text { consumption and economic } \\
\text { growth (1984 - 2007) }\end{array}$ & $\begin{array}{l}19 \text { developed and } \\
\text { developing countries }\end{array}$ & $\begin{array}{l}\text { Panel-based ADF } \\
\text { test, nonparametric } \\
\text { panel unit root tests }\end{array}$ & $\begin{array}{l}\text { In the short run, } \\
\text { nuclear energy } \\
\text { consumption plays a } \\
\text { key role in reducing } \\
\text { carbon emissions while } \\
\text { renewable energy } \\
\text { consumption does not }\end{array}$ & \\
\hline 9. & $\begin{array}{l}\text { Mohamed, Jebli, } \\
\text { and Youssef (2019) }\end{array}$ & $\begin{array}{l}\text { To investigate the dynamic } \\
\text { relationships between } \\
\text { terrorism, renewable energy } \\
\text { consumption, fossil energy } \\
\text { consumption, economic } \\
\text { growth and trade openness } \\
\text { ratio }(1980-2015)\end{array}$ & France & $\begin{array}{l}\text { Auto-Regressive } \\
\text { Distributed Lag } \\
\text { bounds approach, } \\
\text { Granger Causality } \\
\text { Test, ADF }\end{array}$ & $\begin{array}{l}\text { Terrorism can be } \\
\text { combated with an } \\
\text { increase in GDP, and } \\
\text { renewable energy must } \\
\text { be further consumed } \\
\text { due to its beneficial } \\
\text { effects on } \\
\text { environmental and } \\
\text { economic growth }\end{array}$ & Growth hypothesis \\
\hline 10. & $\begin{array}{l}\text { Eren, Taspinar, and } \\
\text { Gokmenoglu (2019) }\end{array}$ & $\begin{array}{l}\text { To ascertain the impact of } \\
\text { financial development and } \\
\text { economic growth on } \\
\text { renewable energy } \\
\text { consumption (1971 - 2015) }\end{array}$ & India & $\begin{array}{l}\text { Dynamic OLS, } \\
\text { Granger Causality }\end{array}$ & $\begin{array}{l}\text { Renewable energy } \\
\text { consumption and } \\
\text { economic growth are } \\
\text { functions of financial } \\
\text { development in the } \\
\text { long run }\end{array}$ & $\begin{array}{l}\text { Feedback } \\
\text { hypothesis }\end{array}$ \\
\hline
\end{tabular}




\begin{tabular}{|c|c|c|c|c|c|c|}
\hline $\mathbf{S} / \mathbf{N}$ & Authors \& Year & Aim & Country & Methodology & Findings & Causality Nexus \\
\hline 11. & $\begin{array}{l}\text { Akadiri, Alola, } \\
\text { Akadiri, and Alaola } \\
(2019)\end{array}$ & $\begin{array}{l}\text { To determine the causal and } \\
\text { long-run relationship } \\
\text { between renewable energy } \\
\text { consumption, environmental } \\
\text { sustainability and economic } \\
\text { growth }(1995 \text { - 2015) }\end{array}$ & $28 \mathrm{EU}$ countries & $\begin{array}{l}\text { Auto-Regressive } \\
\text { Distributed Lag }\end{array}$ & $\begin{array}{l}\text { A positive and } \\
\text { significant long-run } \\
\text { nexus exists between } \\
\text { environmental } \\
\text { sustainability, renewable } \\
\text { energy consumption } \\
\text { and economic growth }\end{array}$ & Growth hypothesis \\
\hline 12. & $\begin{array}{l}\text { Adams, Klobodu, } \\
\text { and Apio (2018) }\end{array}$ & $\begin{array}{l}\text { To study the effects of } \\
\text { renewable and non- } \\
\text { renewable energy } \\
\text { consumption on economic } \\
\text { growth }(1980-2012)\end{array}$ & $\begin{array}{l}30 \text { Sub-Saharan } \\
\text { African countries }\end{array}$ & $\begin{array}{l}\text { Dynamic OLS, fully } \\
\text { modified OLS }\end{array}$ & $\begin{array}{l}\text { Despite both renewable } \\
\text { and non-renewable } \\
\text { energy having a major } \\
\text { positive effect on } \\
\text { economic growth, non- } \\
\text { renewable energy has a } \\
\text { higher growth- } \\
\text { enhancing effect than } \\
\text { renewable energy }\end{array}$ & Growth hypothesis \\
\hline 13. & $\begin{array}{l}\text { Ulusoy and } \\
\text { Demiralay (2017) }\end{array}$ & $\begin{array}{l}\text { To examine the effect of } \\
\text { stock market developments } \\
\text { on oil and electricity demand } \\
(1996-2011)\end{array}$ & $\begin{array}{l}\text { OECD member } \\
\text { nations }\end{array}$ & $\begin{array}{l}\text { Partial Adjustment } \\
\text { Model (PAM), } \\
\text { Generalized Method } \\
\text { of Moments (GMM) }\end{array}$ & $\begin{array}{l}\text { Income, real prices, size } \\
\text { of the stock market and } \\
\text { liquidity are important } \\
\text { determinants of oil and } \\
\text { electricity demand }\end{array}$ & \\
\hline 14. & $\begin{array}{l}\text { Ackah and Kizys } \\
(2015)\end{array}$ & $\begin{array}{l}\text { To explore the drivers of } \\
\text { renewable energy demand in } \\
\text { oil-producing countries } \\
(1985 \text { - 2010) }\end{array}$ & $\begin{array}{l}\text { Algeria, Angola, } \\
\text { Cameroon, Congo, } \\
\text { Ivory Coast, DRC, } \\
\text { Nigeria, Ghana, } \\
\text { Egypt, Sudan, } \\
\text { Tunisia, South Africa }\end{array}$ & GMM & $\begin{array}{l}\text { The main drivers of } \\
\text { renewable energy } \\
\text { demand are real income } \\
\text { per capita, energy } \\
\text { resource depletion per } \\
\text { capital, carbon } \\
\text { emissions per capital } \\
\text { and energy prices }\end{array}$ & \\
\hline
\end{tabular}




\begin{tabular}{|c|c|c|c|c|c|c|}
\hline $\mathbf{S} / \mathbf{N}$ & Authors \& Year & Aim & Country & Methodology & Findings & Causality Nexus \\
\hline 15. & $\begin{array}{l}\text { Jingchao and } \\
\text { Kotani (2012) }\end{array}$ & $\begin{array}{l}\text { To empirically examine } \\
\text { energy demand }\end{array}$ & China & $\begin{array}{l}\text { The survey, Tobit } \\
\text { regression }\end{array}$ & $\begin{array}{l}\text { Renewable energy } \\
\text { technologies are } \\
\text { identified to reduce coal } \\
\text { consumption and } \\
\text { improve energy } \\
\text { efficiency. A rise in coal } \\
\text { and oil prices has } \\
\text { negative effects on their } \\
\text { usage }\end{array}$ & \\
\hline 16. & $\begin{array}{l}\text { Yao, Zhang, and } \\
\text { Zhang (2019) }\end{array}$ & $\begin{array}{l}\text { To detail how renewable } \\
\text { energy consumption can } \\
\text { affect the turning point of } \\
\text { the EKC }(1990 \text { - 2014) }\end{array}$ & $\begin{array}{l}7 \text { emerging } \\
\text { economies and } 10 \\
\text { MDCs }\end{array}$ & $\begin{array}{l}\text { Fully Modified OLS, } \\
\text { dynamic OLS }\end{array}$ & $\begin{array}{l}\text { A long-run relationship } \\
\text { exists between } \\
\text { economic growth, } \\
\text { carbon emissions and } \\
\text { renewable energy rate }\end{array}$ & $\begin{array}{l}\text { Conservation } \\
\text { hypothesis, EKC } \\
\text { hypothesis }\end{array}$ \\
\hline 17. & $\begin{array}{l}\text { da Silva, Cerqueira, } \\
\text { and Ogbe (2018) }\end{array}$ & $\begin{array}{l}\text { To analyze the determinants } \\
\text { of renewable energy growth } \\
(1990-2014)\end{array}$ & $\begin{array}{l}17 \text { Sub-Saharan } \\
\text { African nations }\end{array}$ & Panel-ARDL model & $\begin{array}{l}\text { Economic development } \\
\text { and rising use of energy } \\
\text { lead to renewable } \\
\text { energy development, } \\
\text { while population } \\
\text { growth slows it down }\end{array}$ & EKC hypothesis \\
\hline 18. & Acheampong (2018) & $\begin{array}{l}\text { To examine the causal } \\
\text { relationship between GDP, } \\
\text { carbon emissions and energy } \\
\text { consumption (1990 - 2014) }\end{array}$ & 116 countries & $\begin{array}{l}\text { Panel Vector Auto } \\
\text { Regression (VAR), } \\
\text { System-GMM }\end{array}$ & $\begin{array}{l}\text { At global and regional } \\
\text { levels, economic growth } \\
\text { does not cause energy } \\
\text { consumption }\end{array}$ & $\begin{array}{l}\text { Neutrality } \\
\text { hypothesis, EKC } \\
\text { hypothesis }\end{array}$ \\
\hline 19. & Adewuyi (2016) & $\begin{array}{l}\text { To estimate the } \\
\text { determinants of import } \\
\text { demand for refined } \\
\text { petroleum products (1984 - } \\
2013 \text { ) }\end{array}$ & Nigeria & $\begin{array}{l}\text { ARDL, Bounds } \\
\text { cointegration test }\end{array}$ & $\begin{array}{l}\text { Real effective exchange } \\
\text { rate, GDP, population } \\
\text { growth rate, domestic } \\
\text { energy production are } \\
\text { all drivers of import of } \\
\text { petroleum products }\end{array}$ & \\
\hline
\end{tabular}




\begin{tabular}{|l|l|l|l|l|l|l|}
\hline S/N & Authors \& Year & \multicolumn{1}{|c|}{ Aim } & \multicolumn{1}{c|}{ Country } & \multicolumn{1}{c|}{ Methodology } & \multicolumn{1}{c|}{ Findings } \\
\hline 20. & $\begin{array}{l}\text { Paramati, } \\
\text { Bhattacharya, } \\
\text { Ozturk, and Zakari } \\
(2018)\end{array}$ & $\begin{array}{l}\text { To identify the key factors } \\
\text { driving energy consumption } \\
\text { in frontier market economies } \\
(1991-2012)\end{array}$ & $\begin{array}{l}\text { Botswana, Ghana, } \\
\text { Kenya, Morocco, } \\
\text { Nigeria, Tunisia and } \\
\text { Zimbabwe }\end{array}$ & $\begin{array}{l}\text { Fully Modified OLS, } \\
\text { heterogeneous panel } \\
\text { non-causality test }\end{array}$ & $\begin{array}{l}\text { Industrialization and } \\
\text { internalization will lead } \\
\text { to energy saving for } \\
\text { most of the countries }\end{array}$ \\
\hline 21. & $\begin{array}{l}\text { Sarkodie and } \\
\text { Adom (2018) }\end{array}$ & $\begin{array}{l}\text { To examine the drivers of } \\
\text { aggregate energy } \\
\text { consumption, fossil fuel and } \\
\text { electricity consumption } \\
(1971-2014)\end{array}$ & Kenya & $\begin{array}{l}\text { Non-Iterative Partial } \\
\text { Least Squares } \\
\text { Method (NIPALS) }\end{array}$ & $\begin{array}{l}\text { Price, urbanization and } \\
\text { renewable hydro energy } \\
\text { have promoted energy } \\
\text { demand reduction }\end{array}$ \\
\hline
\end{tabular}

